\section{A Model for the Stratification of Dairy and Mutton Sheep Breeds in Middle Eastern Deserts}

\section{MORAG 1}

Animal Physiologist, Negev Institute for Arid Zone Research, Beer Sheva, Israel.

\section{Highlight}

A model is proposed in which desert regions are integrated into the sheep production of more fertilc areas of the Middle East. A system of stratification of sheep breeds in which range sheep adapted to desert conditions are mated with high quality dairy and mutton breed rams, and their progeny are transferred for milk and fat-lamb production to intensive farms is set out and discussed. The model is presented in the context of the exploding population and the shortage of animal protein in the Middle East.

${ }^{1}$ I wish to thank Prof. W. V. Macfarlane, Prof. H. Epstein, Prof. A. Berman, Dr. E. Eyal and Mr. R. Benjamin for discussions on the animal aspects of the proposed model, and Mr. M. Forti, Mr. Y. Ofer and Mr. Y. Orev for information on desert pasture. I am grateful to Mr. E. Rubin for his help in preparing this manuscript and for designing the figures.

\section{Sheep Stratification Systems}

The stratification of breeds is a characteristic of mature populations of domestic animals in many parts of the world. By stratification marginal or even sub-marginal land is, through a system of crossbreeding, integrated into the animal production systems of more fertile regions. In this way total agricultural output is increased. Stratification systems have been described by various authors (e.g., Darling, 1934; Hammond, 1936, 1952; Nichols, 1957; Epstein, 1965).

In a stratified sheep population the foundation stock consists of a breed fully adapted to the adverse environment of the marginal area. (Land may be marginal for many reasons e.g. very high or very low rainfall, unsatisfactory distribution of rainfall, high altitude, extreme temperatures, soil type, etc.). The foundation breed is characterized by ewes which are hardy, thrifty and are able to produce and raise lambs under adverse conditions. The breed is usually late-maturing and the carcass is invariably of a low quality. When transferred to an environment more suitable for intensive sheep raising and crossed with a ram from an earlier maturing breed, the ewes are capable of producing a high quality 


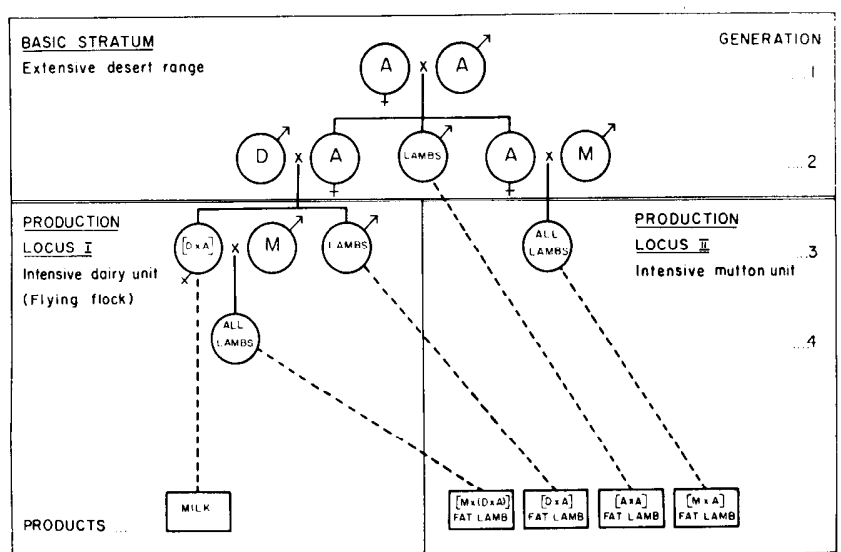

Fig. 1. General form of the suggested model for the stratification of a basic sheep breed (A) crossed with dairy (D) and with mutton (M) breed rams.

fat lamb. If the stratified system is to be economically viable, then the raising of the foundation ewes in the marginal area and their transfer for crossing to the better environment must be more profitable than the raising of mutton type replacement ewes for pure breeding in the fertile area.

Sheep stratification systems can consist of two environments with a single cross-mating as, for example, in Australia where cull Merino ewes from the dry ranges are brought into the wheat belt and are crossed with Longwool or Down breed rams. Alternatively the system can include three environments with two or even three cross-matings as in Great Britain. In this case, late-maturing Mountain breed ewes are brought down after 3 or 4 lambings to the hill pastures and crossed with Border Leicester rams. The male lambs are slaughtered, while the female half-breds are taken further down the hill to valley paddocks, or to arable land, for crossing with Down-type rams to give top quality fat lamb. A further mating of the females of the second cross with Down rams is sometimes carried out. (For details of these systems see Nichols, 1957 and Epstein, 1965.)

Although stratification systems for the production of mutton and wool (Epstein, 1965) have been developed, no system for the production of ewe milk has been described.

\section{Components of the Suggested Model}

\section{General Form}

The general form of a suggested system of stratification is presented in Figure 1. The basic stratum consists of desert range where the foundation stock is raised on pasture. The ewes of the basic breed (A) are crossed with either dairy (D) or early maturing mutton (M) breed rams. The progeny derived from the dairy and mutton crosses are transferred to the relevant intensive management production loci for either milk (I) or fat lamb (II) production.

\section{Basic Stratum}

The basic stratum is composed of arid and semiarid land. Indices of aridity based on elements of weather and climate have been proposed by Thornwaite (1948). These have been used by Meigs (1953) to map and classify the deserts of the world. In the context of this model, areas defined as arid or semi-arid zones coincide in general terms with those areas which, because of lack of moisture, are unable to produce regular economic cereal crops in a dry farming system, but which are, on the other hand, able to support varying amounts of pasture plants and shrubs. The annual rainfall of this type of land is between 150 and $300 \mathrm{~mm}$. Vast areas of the Middle East fall into this category. These regions are at present either extensively grazed by unimproved nomadic flocks of sheep or goats or are unexploited.

Recent work in the Northern Negev desert in Israel has shown that by careful pasture and animal management stocking rates as high as one ewe per 0.6 ha can be attained even when the annual rainfall does not exceed $230 \mathrm{~mm}$ (Tadmor et al., 19631971; Tadmor et al., 1971). The carrying capacity and the seasonal pattern of plant production of such pastures can be further improved by the introduction of leguminous and non-leguminous species of shrubs (Forti, 1970, 1971). Assuming a minimal stocking rate of one ewe per ha the sheep population of the Northern Negev would reach 260,000 head. At present the same area supports only some 80,000 unimproved sheep and goats in low producing nomadic Bedouin flocks. It is assumed that similar improvements could be made in other arid and semi-arid areas of the Middle East.

In addition to the arid and semi-arid zones defined above, the basic stratum would include land which although it enjoyed a higher rainfall, is for various reasons unsuitable for arable or horticultural development.

\section{Foundation Stock}

The foundation stock must be hardy and fecund in the adverse environment of the desert range. Furthermore, the basic ewes must, when sired by a dairy ram, produce a potentially high yielding milk ewe and when sired by a mutton ram, an early maturing high quality fat lamb. The ewes must have strong legs, be good grazers and be heat and drought resistant. The Awassi ewe appears to bc a suitable initial choice for a foundation breed, at least in the Middle East. With the development of the system the basic (Awassi) ewe would probably either be replaced or improved. Fertility could be increased by the introduction of Finnish (or other relevant) genes. Furthermore, with the rise in the standard of living in Middle Eastern countries the demand for prime quality fat lamb will increase 
Table 1. The proportion of mutton (m) and dairy (d) genes in lambs derived from crosses in Figures 1 and 2. The proportions are shown when the basic breed is either Awassi or an Awassi-Merino hybird.*

\begin{tabular}{lcc}
\hline $\begin{array}{c}\text { Designation of } \\
\text { lamb in }\end{array}$ & $\begin{array}{c}\text { Proportion of } \\
\text { m to d genes } \\
\text { when the basic } \\
\text { breed is Awassi }\end{array}$ & $\begin{array}{c}\text { Proportion of } \mathrm{m} \text { to d } \\
\text { genes when the basic } \\
\text { breed is in } \\
\text { Awassi-Merino hybrid }\end{array}$ \\
\hline $\mathrm{M} \times(\mathrm{D} \times \mathrm{A})$ & $0.50 \mathrm{~m}: 0.50 \mathrm{~d}$ & $0.75 \mathrm{~m}: 0.25 \mathrm{~d}$ \\
$\mathrm{D} \times \mathrm{A}$ & $0.00 \mathrm{~m}: 1.00 \mathrm{~d}$ & $0.25 \mathrm{~m}: 0.75 \mathrm{~d}$ \\
$\mathrm{~A} \times \mathrm{A}$ & $0.00 \mathrm{~m}: 1.00 \mathrm{~d}$ & $0.50 \mathrm{~m}: 0.50 \mathrm{~d}$ \\
$\mathrm{M} \times \mathrm{A}$ & $0.50 \mathrm{~m}: 0.50 \mathrm{~d}$ & $0.75 \mathrm{~m}: 0.25 \mathrm{~d}$ \\
$\mathrm{M} \times(\mathrm{D} \times(\mathrm{D} \times \mathrm{A}))$ & $0.50 \mathrm{~m}: 0.50 \mathrm{~d}$ & $0.56 \mathrm{~m}: 0.44 \mathrm{~d}$ \\
$\mathrm{D} \times(\mathrm{D} \times \mathrm{A})$ & $0.00 \mathrm{~m}: 1.00 \mathrm{~d}$ & $0.22 \mathrm{~m}: 0.88 \mathrm{~d}$ \\
\hline
\end{tabular}

* The table is based on the assumptions that both mutton and dairy characteristics are specified by a large number of independently assorting genes and that the Awassi-Merino hybrid has $50 \%$ of its genes from each parent breed.

and thus necessitate an improvement of the mutton qualities of the basic breed. This could be achieved by developing a new breed based on the native Awassi and a mutton-type animal.

While a critical research program is required to establish which breed or breeds are suitable to improve the carcass quality of the Awassi, preliminary experience has shown the German Mutton Merino to be a fertile and an early maturing quality fat lamb breed in a hot desert climate (Goot, 1967; $\mathrm{H}$. Goot, unpublished data). The nature of the foundation breed, whether pure Awassi or say an AwassiMcrino hybrid, would affect the genetic make up of the lambs produced throughout the stratification. Table 1 sets out the proportion of mutton and of dairy genes in the lambs derived from the crosses in Figures 1 and 2 when the basic breed is an Awassi or is an Awassi-Merino hybrid. The table is based on the assumption that both mutton and dairy characteristics are specified by a large number of independently assorting genes. The introduction of Merino genes into the basic stratum would contribute to the improvement of the wool quality throughout the system. Under present (economic) conditions the improvement of wool quality is less important than the improvement of fertility, carcass quality or milk yield. Improvement of fertility or of meat quality of the foundation stock must not be at the expense of the ewes' ability to survive and to thrive on the desert range.

In most sheep stratification systems (see Nichols, 1957; Epstein, 1965) cull ewes from the basic stratum are transferred to more intensive strata for cross-breeding. In the proposed model the foundation ewes would not leave the basic stratum. The mutton and dairy cross-mating would take place in the basic stratum and only the progeny would be transferred to the production loci.

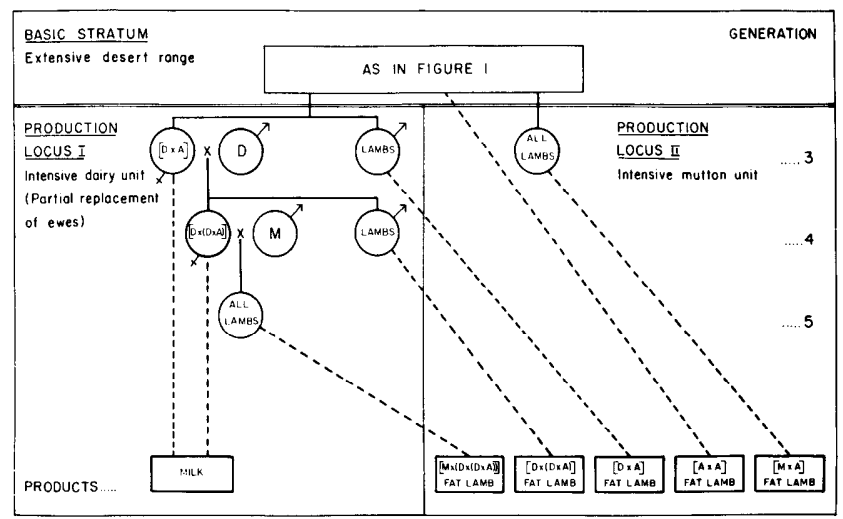

FIG. 2. Production loci of the stratification system in which the dairy unit uses a dairy (D) breed ram to give partial replacement of milking ewes.

Pasture and Animal Management in the Basic Stratum

The success of any stratification system is primarily a function of the productivity of the basic stratum ecosystems. A high level of primary and of secondary production can only be achieved by sophisticated and integrated systems of management. This will not be easy to achieve. In the Middle East social, religious and economic factors and problems associated with land tenure may inhibit the development of a modern organizational framework. The ultimate goal must be a fully coordinated breeding program, with pasture improvement, grazing management and livestock movement controlled by a central agency. The usc of artificial insemination and modern methods of data collection and handling will be necessary to ensure that genetic selection for desired traits be efficient. Artificial insemination or at least assisted hand-mating is necessary whenever fat-tailed (Awassi) ewes are crossed with non-fat tailed rams. The latter are unable to achieve penis penetration because of their behavioral inability to push the ewes' fat tail aside.

Feed and fodder for the basic breed will be provided by the (improved) range pasture. In drought years supplementary feed may have to be provided to ensure continuity of production or in extreme cases the survival of the ewes. Furthermore, with the development of hormonal and nutritional techniques for increasing the frequency of lambing (see Hunter, 1968a and b for discussion of these trends) one can foresee that even under these extensive conditions ewes could be made to lamb twice-a-year. Flushing on the range could be achieved by fencing off specially improved plots and grazing them only during the mating season, or by irrigating small areas of high producing fodder crops using flood water conserved by diversion or detention dams (Y. Orev, personal communication). In the extreme case and when the economic 
situation justifies it, one would import feed from non-desert areas.

The weaning procedure of the lamb will be determined by the availability of pasture during the post partum period. The recent development of successful artificial rearing systems based on cheap milk substitutes or dry concentrate foods (Owen, 1969; Owen and Davis, 1970) offers an alternative method of raising lambs. The decision whether to suckle the lambs or to raise them in an artificial rearing system (probably in Locus II) would be an economic one. The artificial rearing of lambs would relieve the grazing pressure in the basic stratum and thus enable more ewes to be carried per unit area. Early weaning may be important in the terms of post partum conception (Copenhaver and Carter, 1964, 1966).

\section{The Dairy Cross}

The number of foundation ewes mated (or inseminated) with dairy type rams would be controlled by the demand for ewes' milk. The most suitable dairy ram for hot regions at present available is the Israeli hybrid dairy sheep derived from the Improved Awassi (5/8) and from the East Friesian (3/8) breeds. (Goot, 1965; Eyal and Goot, 1968; E. Eyal, unpublished data). The high yielding hybrid is more fertile in an intensive production system than either parent breed. This type of animal may well be the prototype for a high yielding dairy ewe for the hot areas of the Mediterranean Basin. In the system as set out in Figure 1, the dairy ewes $[\mathrm{D} \times \mathrm{A}]$ are put to a mutton type-ram (Locus I Generation 3). All progeny from this cross are transferred to Locus II for fat-lamb production. The dairy unit is therefore, by definition a 'flying' flock which does not breed any replacement ewes. In such a flock all the milk sheep are bred out in the basic stratum. This structure could be made more flexible by mating the $[\mathrm{D} \times \mathrm{A}]$ ewes with a dairy type rather than with a mutton-type ram (see Figure 2, Locus I, Generation 3). This would create a dairy flock which breeds a proportion of its own replacement ewes. The second dairy cross would give lambs with a high proportion of dairy genes $[D \times(D \times A)]$. The female progeny would be milked and the male lambs fattened to give a relatively low quality carcass. A further cross (Generation 4) would be made using a mutton-type ram and all lambs resulting from this mating would be transferred to Locus II for fattening (see Figure 2). The annual production cycle of the dairy flock would be based on two lambings and two short high lactations per year as described by Morag and Eyal (1971).

The Mutton Cross

The choice of ram for this cross is an open one. The limited experience available on the perform- ance of Down rams in the Negev desert indicates, as mentioned above, that the German Mutton Merino is well adapted and yields early-maturing high quality lambs. It may be that other breeds are just as suitable. If, at a later stage, the basic breed were to contain a proportion of Merino genes (as suggested above), then the mutton cross would be carried out using rams of a different mutton breed. This will ensure hybrid vigor in the lambs which are transferred for fattening to Locus II.

\section{The Production Loci}

The characteristic of the production loci is that they are intensive agricultural units. This implies that feed, both roughage and concentrates, are readily available from local or from outside sources. The loci would be situated either in the extensive range around water sources or conduits associated with rural or even with urban development, or alternatively, in non-desert areas some distance from the basic stratum. The development of agricultural settlements along the water carrier in the Northern Negev (Rokach, 1964) serves as an example of the former situation and the Scottish stratification with the transfer of lambs from the mountains to distant arable areas as an example of the second.

The size of the intensive units of the production loci would be determined by economic and general agricultural factors. Both the milking and the fattening operations lend themselves to large-scale mechanized operations with attendant economy of scale. On the other hand both operations could be viable in small holdings and family farms.

\section{Summary}

The integration of the animal production of marginal desert areas with that of intensive farming systems offers the (subsistence) pasturalist an opportunity to improve his lot and his livelihood without abandoning his traditional way of life. In the present system the number of sheep in the pasturalists' flock fluctuate from year to year in accordance with the availability of pasture. These often violent fluctuations are a source of insecurity to the desert shepherd. The flexibility of the proposed model, with the movement of stock, artificial rearing systems and the possibility of importing food onto the range, offers the pasturalist a higher degree of economic stability.

Development of a model similar to that proposed in this paper could lead to a large increase in the protein production of desert areas and also contribute to the improvement of the social and economic welfare of desert dwellers.

\section{Literature Cited}

Copenhaver, J. S., and R. C. Carter. 1964. Maximizing ewe productivity by very early weaning and rebreeding. J. Anim. Sci. 23:302. 
Copenhaver, J. S., and R. C. Carter. 1966. Early weaning and multiple weaning. Progr. Rep. Va. Agr. Exp. Sta. 1965-6:54-57

Darling, F. F. 1934. Animal breeding in the British Empire. Imperial Bureau of Animal Genetics, Edinburgh. $47 \mathrm{p}$.

EPstfin, H. 1965. Regionalisation and stratification in livestock breeding. Anim. Breed. Abstr. 33:169-181.

Eyal, E., AND H. Goot. 1968. Vital statistics and milk and lamb production of $\mathbf{F}_{1}$ ewes (Awassi $\times$ East Friesian) under farm conditions. Volcani Inst. Agr. Res. Pam. 120:1-24.

ForTI, M. 1970. Grazing trials on perennial fodder bushes. Preliminary report: Negev Institute for Arid Zone Research, Beer Sheva. May 1970.

ForTI, M. 1971. The introduction and cvaluation of fodder shrubs in semi-arid areas of the Northern Negev. Submitted for publication.

Goot, H. 1965. Studies on the native Awassi sheep and its crosses with exotic East Friesian milk sheep. Ph.D. thesis. Hebrew University, Jerusalem. (Hebrew).

Goot, H. 1967. Some data on out of season lambing in mutton Merino ewes. Israel J. Agr. Res. 17:219-224.

Hammond, J. 1936. Environmental conditions and livestock breeding. Probl. Zivotn 1936:101-112.

Hammond, J. 1947. Animal breeding in relation to nutrition and environmental conditions. Biol. Rev. (Camb.) 22:195-223.

Hunter, G. L. (1968a). Increasing the frequency of pregnancy in sheep. I. Some factors affecting rebreeding during the post partum period. Anim. Breed. Abstr. 36: 347-378.

Hunter, G. L. (1968b). Increasing the frequency of pregnancy in sheep. II. Artificial control of breeding and prob- lems of conception and maintenance of pregnancy during the post partum period. Anim. Brecd. Abstr. 36:533-553.

Meigs, P. 1953. World distribution of arid and semi-arid homoclimates. In 'Reviews on research on arid zone hydrology'. Arid Zone Programme I. Unesco, Paris. p. 203$210+2$ maps.

Morag, M., and E. Eyal. 1971. Post partum conception in lactating Awassi and East Friesian $\times$ Awassi dairy ewes. J. Agr. Sci. 77:109-116.

Nichols, J. E. 1957. Livestock improvement in relation to heredity and environment. 4th ed. Oliver and Boyd, Edinburgh. $240 \mathrm{p}$.

OwEN, J. B. 1969. The intensification of sheep production. Outlook Agr. 6:36-40.

Owen, J. B., And D. A. R. Davies. 1970. Milk replacers in the artificial rearing of lambs. J. Sci. Food Agr. 21: 340-341.

Pearse, C. K. 1971. Grazing in the Middle East: past, present and future. J. Range Manage. 24:13-16.

RoкACH, A. 1964. Land and water. In 'Agricultural planning and village community in Israel.' Arid Zone Research XXIII. Ed. J. Ben David. Unesco, Paris. p. 13-20.

Tadmor, N. H., E. Eyal, R. Benjamin, L. Shanan, N. Seligman, and B. Yogev. 1963-1970. Dryland range in the Northern Negev of Israel. 1. 1962/63 2. 1963/64 3. $1964 / 65$ 4. 1965/66 5. 1966/67 6. 1967/69. Progr. Rep. Volcani Inst. Agr. Res.

Tadmor, N. H., E. Eyal, and R. Benjamin. 1971. Primary and secondary production of arid grassland. Paper submitted to IBP Seminar 'Ecophysiological basis of Arid Zone ecosystem productivity' to be held in Leningrad, 1972.

Thornwaite, C. W. 1948. An approach towards a rational classification of climate. Geogr. Rev. 38:55-94. 